Brit. J. industr. Med., 1965, 22, 128.

\title{
AIR POLLUTION IN A CITY STREET
}

BY

\author{
R. E. WALlER, B. T. COMMINS, and P. J. LAWTHER \\ From the Medical Research Council, Air Pollution Research Unit, \\ St. Bartholomew's Hospital Medical College, London, E.C.1
}

(RECEIVED FOR PUBLICATION FEBRUARY 15, 1965)

\begin{abstract}
Measurements of the concentrations of smoke, lead, and five polycyclic hydrocarbons in the air have been made in the City of London in the middle of a busy street and at two control sites. Samples were taken only throughout the daytime hours on weekdays to enable us to assess the maximum contribution made by traffic to the pollution in the street. The results showed that during these periods the air in the middle of the street contained three times as much smoke, four times as much lead, and 1.7 times as much 3:4-benzpyrene as were present in the general atmosphere of the City of London as estimated from samples taken at the control sites. One of these sites was chosen because it was only 150 feet away from the street; analyses yielded no evidence that the traffic contributed to the pollution sampled there. Sulphur dioxide concentrations were determined in the early part of the study and the results showed that traffic appeared to add little to the background level. The concentrations of lead found were below those held to be safe by many authorities. Carbon monoxide concentrations, reported in greater detail elsewhere, sometimes reached the accepted industrial maximum allowable concentration of 100 p.p.m.
\end{abstract}

The Report of the Committee on Air Pollution (1954) stated that 'The contribution of exhaust gases to the total volume of air pollution is still relatively small, but it can reach considerable proportions locally in areas of heavy traffic congestion where the movement of air is restricted'. Despite a substantial increase in motor traffic and a welcome reduction in the amount of coal smoke, the situation has not changed radically since 1954 , and the statement remains valid for Great Britain as a whole. In an earlier paper (Waller, Commins, and Lawther, 1961) we reported the results of a study of the highest concentrations of traffic pollution likely to be encountered. In the Blackwall Tunnel, where there is much congestion and the ventilation is poor at all times, we found high concentrations of smoke, lead, polycyclic hydrocarbons, and carbon monoxide. An attempt to determine which type of traffic (petrol or diesel) was responsible for the emission of each of these pollutants gave inconclusive results, and further work on this aspect of the problem is in progress.

Having determined what were for practical purposes upper limits of pollution by motor traffic we turned our attention to pollution in a busy street. A suitable site was found in Fleet Street, a rather narrow congested street with poor natural ventilation, used during working hours by traffic of all types and by many pedestrians; a control site was found nearby. In the Blackwall Tunnel the ventilation was controlled, and we were therefore able to relate hourly measurements of pollution to the amount of traffic; in the open air, however, variations in wind speed and direction, which would cause erratic fluctuations in the dispersion of pollution, made this type of approach impracticable. We planned instead to take samples over long periods so as to obtain the mean concentrations of pollutants over a wide range of weather and to compare the results with those obtained at our main control site. Samples were also taken at our laboratory to provide further information about 'background' levels of pollution. A more detailed study was made of the concentration of carbon monoxide, and the results have already been reported (Lawther, Commins, and Henderson, 1962). The present paper deals mainly with pollution by smoke, lead, and polycyclic hydrocarbons.

\section{Sampling Sites}

All three sampling sites selected are in the City, the one square mile business centre of London, and 


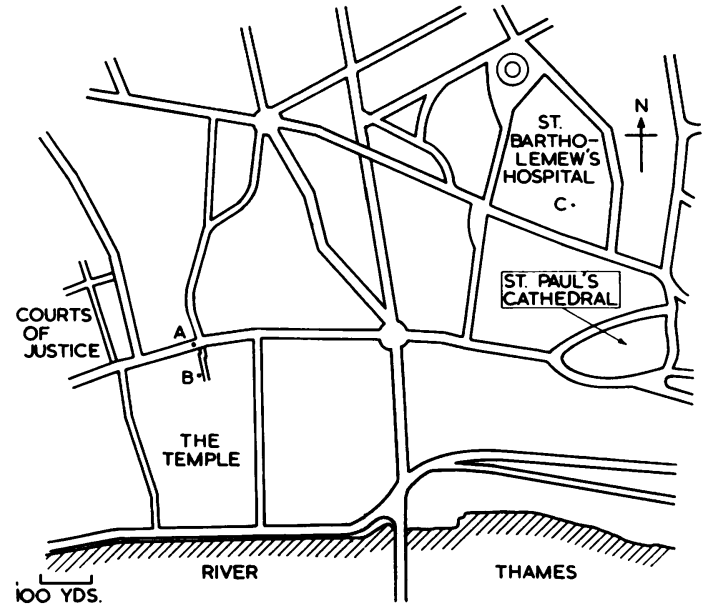

FIG. 1. Sketch map of part of the City of London, showing sampling points $A, B$, and $C$.

their positions are shown in Figure 1. The main sources of 'background' pollution in this area are central heating installations which commonly emit sulphur dioxide: the emission of smoke from chimneys is prohibited, but some coal smoke, with its associated polycyclic aromatic hydrocarbons, drifts in from other parts of London.

The street samples were collected at site A (Fig. 1) on an island in the middle of Fleet Street. The apparatus was placed just below ground in the entrance to a public convenience; the air inlet was about 4 feet ( 1.2 metres) above road level and was connected to the apparatus by a short length of plastic tubing and steel conduit. The total width of the road and pavements at this point is 55 feet (17 metres); the one-way street (Fetter Lane) that enters Fleet Street here is only 25 feet $(8$ metres) wide. On each side of Fleet Street is a continuous line of buildings approximately 50 feet (15 metres) high, and the sampling site is thereby somewhat sheltered from strong winds. Traffic movements at the junction were at the time of the experiments controlled by a policeman, and the directions of flow are shown in Figure 2. Vehicles frequently halt at the junction and were usually accelerating as they passed the inlet. We chose as the control site a building (B) in Mitre Court, only 150 feet (46 metres) from site A; it was screened from Fleet Street by buildings and was thought to be relatively unaffected by traffic pollution. We were able to place our apparatus in a room on the fourth floor, with the intake about 35 feet (11 metres) higher than the one in Fleet Street. The sampling site in our laboratory at St. Bartholomew's Hospital (C), half a mile ( 800 metres) from Fleet Street, was also remote from traffic, and the air inlet was about 100 feet ( 30 metres) above the one in Fleet Street.

\section{Traffic Counts}

Although the measurements of pollution could not be related strictly to the number and type of vehicles passing the sampling point, counts were made from time to time to assist in any comparison which might be made with results from other studies. Vehicles were counted as they passed in either direction along Fleet Street (Fig. 2) past the sampling point.

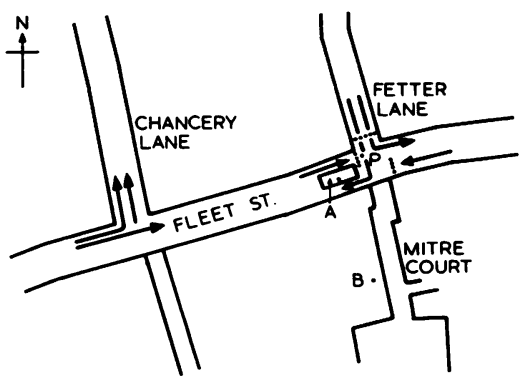

FIG. 2.-Diagram showing traffic flow near sampling point $A$. At the time of the investigation there was a policeman $(P)$ on duty at the junction and traffic halted at the points shown by the dotted lines.

The mean flow calculated from all of the counts made between 08.00 and 19.00 hours (the period selected for most of the sampling operations) was 1,800 vehicles per hour, comprising 1,200 petrol and 600 diesel vehicles. Although the proportion of diesel vehicles was similar to that found in the Blackwall Tunnel, there was a marked difference in their sizes. Several counts were made in the Blackwall Tunnel and in Fleet Street classifying all the traffic; in the tunnel, $40 \%$ of the vehicles were large diesel trucks or buses with engines of between 31 . and 101 . capacity. In Fleet Street, only $13 \%$ of the vehicles were large diesels, but $27 \%$ were diesel taxis with engines of about 21 . capacity, which were rarely seen in the tunnel.

\section{Sampling and Analytical Methods}

In some preliminary experiments carried out in the summer of 1961, the concentrations of smoke and sulphur dioxide in Fleet Street were measured using the type of apparatus recommended by the British Standards Institution (1964). Smoke was collected on Whatman No. 1 filter paper in a 4-in. diameter holder, and the amount was assessed by measuring the reflectance of the stain; sulphur dioxide was 
absorbed in hydrogen peroxide solution and was determined by measuring the conductivity. At first, samples were collected throughout the day and night, but to obtain the maximum contrast between the pollution in Fleet Street and that at the control site sampling was later limited to the period 08.00 hours to 19.00 hours on Mondays to Fridays. The hours were chosen so as to include the whole of the congested period, and time switches were fitted to each set of apparatus so that this programme could be maintained without attention.

In the next part of the experiment, from September 1961 to January 1962, smoke samples were collected on weighed glass fibre filter papers at sites A and B for direct assessment of mass concentration and analysis for polycyclic hydrocarbons: sulphur dioxide sampling was discontinued. Finally, for a whole year, starting in March 1962, samples were taken in this way at all three sites (A, B, and C) and the analyses were extended to include determinations of lead. The sampling rate was $1 \frac{1}{2}$ to 3 litres of air/minute and filters were changed every one, two or three months, depending on the amount of smoke collected. These filters were bulked in quarterly periods for determination of polycyclic aromatic hydrocarbons and lead: those at the control sites were usually left for the whole three months so that they collected enough smoke to be weighed with reasonable accuracy.

After the filters had been weighed they were extracted with cyclohexane and the extract was evaporated to small volume and transferred to a column of alumina. The hydrocarbons were separated chromatographically by elution with cyclohexane and determined by ultraviolet spectrophotometry (Commins, 1958a). The only hydrocarbons which we measured were 1:2-benzpyrene, 3:4-benzpyrene, 1:12-benzperylene, and anthanthrene, since the hydrocarbons of lower molecular weight, which were also present in the air were too volatile to be collected efficiently by the procedure used (Commins, 1961). Where lead was determined, the filter was divided and a measured fraction of it was extracted with nitric acid; an aliquot of this solution was extracted with a small excess of a solution of dithizone in chloroform, and the excess dithizone was removed by washing with ammonia-potassium cyanide solution (Harrold, Meek, and Holden, 1936). The amount of lead in the extract was estimated colorimetrically. Carbon monoxide was measured by aspirating air through a recording non-dispersive infra-red gas analyser.

\section{Results}

The preliminary experiments were done in the summer months when the background pollution was low. From July 24, 1961 the samplers at Fleet Street and Mitre Court were run for seven consecutive days, and the results (Table 1) showed that there was much more smoke and a little more sulphur dioxide in Fleet Street than at Mitre Court. For the next two weeks samples were collected from Monday to Friday, and separate samples were taken at weekends (Saturday and Sunday) when the traffic was lighter than during the week; the weekend measurement showed the expected reduction in pollution. Finally, the time switches were set to take samples only during the period from 08.00 to 19.00 (Table 1). The smoke concentrations in Table 1 have all been estimated from reflectance measurements. The standard reflectance/mass calibration was used for the Mitre Court samples, but since traffic smoke is blacker than the mixed urban smoke for which the curve was constructed the Fleet Street figures have been derived from the standard curve by dividing by a factor of 2.8 suggested by our subsequent gravimetric experiments. Reed (1963) has suggested dividing by a factor of four when dealing with diesel smoke, but the factor for mixed traffic is likely to be less than this.

Table 1 shows that the concentrations of smoke in Fleet Street were much higher than those at Mitre Court, the difference between the two sites being greatest in samples taken during the congested daytime periods on weekdays. In general the concentrations of sulphur dioxide were only a little higher in Fleet Street than at Mitre Court. During the busy periods (weekday daytime) the difference between the concentrations at the two sites was $44 \mu \mathrm{g} . / \mathrm{m}^{3}$; this small amount may be attributable to traffic. The background concentration of sulphur dioxide as determined at the control site in Mitre Court was even in summer so much higher than this rough

TABLE 1

CONCENTRATION OF SMOKE AND SULPHUR DIOXIDE IN FLEET STREET AND AT CONTROL SITE,

\begin{tabular}{|c|c|c|c|c|c|c|}
\hline \multirow[b]{2}{*}{ Site } & \multicolumn{3}{|c|}{ Smoke ${ }^{*}\left(\mu \mathrm{g} . / \mathrm{m}^{3}{ }^{3}\right)$} & \multicolumn{3}{|c|}{$\mathrm{SO}_{2}\left(\mu \mathrm{g} . / \mathrm{m}^{3}\right)$} \\
\hline & $\mathbf{A}$ & B & Diff. & $\mathbf{A}$ & B & Diff. \\
\hline $\begin{array}{l}\text { July 24-31: } \\
\text { Whole week }\end{array}$ & 150 & 57 & 93 & 202 & 154 & 48 \\
\hline $\begin{array}{l}\text { July 31-August 14: } \\
\text { Monday-Friday } \\
\text { Saturday and Sunday }\end{array}$ & $\begin{array}{l}220 \\
130\end{array}$ & $\begin{array}{l}49 \\
38\end{array}$ & $\begin{array}{r}171 \\
92\end{array}$ & $\begin{array}{l}273 \\
144\end{array}$ & $\begin{array}{l}211 \\
136\end{array}$ & $\stackrel{62}{\dagger}$ \\
\hline $\begin{array}{l}\text { August 14-28: } \\
\text { Monday to Friday, } \\
08.00-19.00 \\
\text { Saturday and Sunday, } \\
08.00-19.00\end{array}$ & 360 & 59 & 301 & 384 & 340 & 44 \\
\hline
\end{tabular}

*Values estimated from reflectance measurements (see text).

$\dagger$ Difference very small. 
estimate of the traffic component that we considered that it would be difficult to make any reliable assessment of the contribution made by traffic. Therefore we did not include any measurements of sulphur dioxide in our longer series of experiments which ran through the winter months.

Measurements of carbon monoxide were made from October 1961 to February 1962. The sharp fluctuations in concentration as individual vehicles passed the sampling inlet were smoothed by the long inlet tube and low sampling rate $(0.7 \mathrm{l} . / \mathrm{min}$.). The continuous record was analysed over hourly periods, noting the mean and the maximum in each case. The main features of the results have already been reported (Lawther et al., 1962); mean values for whole days and for the hours when our smoke measurements were made $(08.00$ to 19.00$)$ are given in Table 2.

\section{TABLE 2}

MEAN CONCENTRATIONS OF CARBON MONOXIDE IN FLEET STREET, OCTOBER, 1961 TO FEBRUARY, 1962

\begin{tabular}{l|c|c|c}
\hline & \multicolumn{2}{|c}{ CO (p.p.m.) } \\
\cline { 2 - 3 } & Weekdays & Weekends & Whole weeks \\
\cline { 2 - 4 } & $9 \cdot 1$ & 4.6 & 7.8 \\
\hline Whole days & 16.6 & 6.2 & 13.6 \\
\hline
\end{tabular}

We did not make any measurements of carbon monoxide at our control site (B) but the concentration has never exceeded about 2 p.p.m. at our laboratory (site $\mathrm{C}$ ). In general the background concentration of carbon monoxide away from streets is too low to be measured by our infra-red analyser, and therefore virtually all of the carbon monoxide found in Fleet Street is attributable to traffic. The diurnal variation (Fig. 3) was clearly related to the amount of traffic: the pattern remained almost constant for the five weekdays (Monday to Friday) with maxima between 09.00 and 10.00 in the morning and between 17.00 and 18.00 in the afternoon. On Thursdays, when shops in central London remain open until 19.00 , evening concentrations were higher than those measured on other weekdays. The highest late-night concentrations were on Saturday nights, and these continued into the early hours of Sunday mornings. At that time there is additional traffic for theatres and other entertainments.

From the combined weekday results we found that the concentration of carbon monoxide remained above 10 p.p.m. for the whole of the period 08.30 to 19.30 hours; this corresponded closely with the limits chosen for our smoke sampling experiments. The most polluted hour of the day was the evening rush hour, from 17.00 to 18.00 hours, and the mean

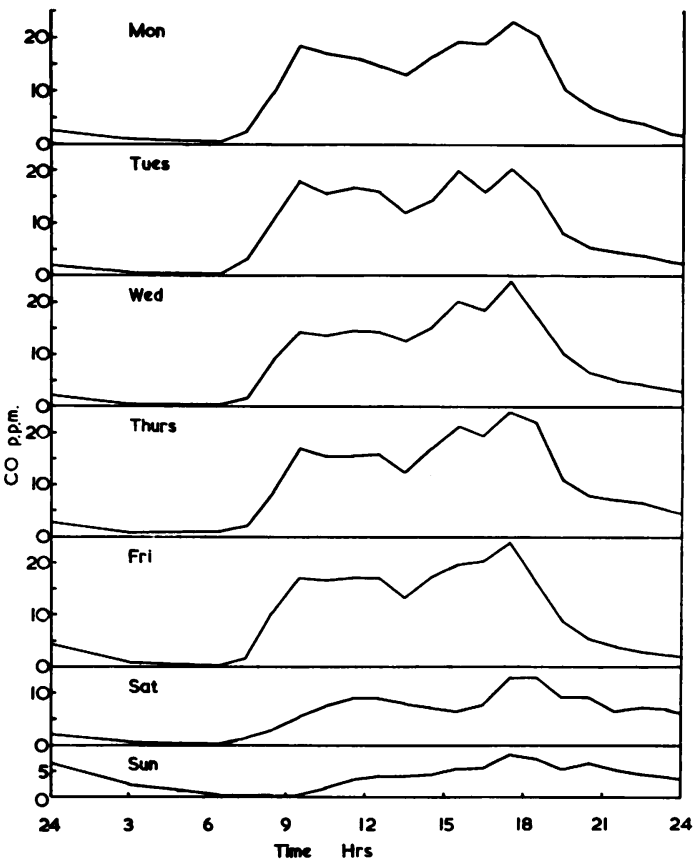

FIG. 3.-Hourly variations in the concentration of carbon monoxide in Fleet Street (site A).

concentration at that time for all weekdays was 23 p.p.m. Sharp peaks of up to 100 p.p.m. occurred throughout the day, and since much of the shortterm variation was damped-out in our sampling system, even higher concentrations must have occurred momentarily in the street.

In the preliminary experiments the smoke in Fleet Street had been determined from measurements of reflectance of the stain on the filter paper, but it was realized that the relationship between reflectance and weight would be different from that for ordinary town smoke. In the main part of the experiment all smoke measurements were made gravimetrically, and by comparing results obtained by the two methods we were able to estimate the weight of smoke collected in the preliminary experiments (Table 1).

The results of determinations of smoke and polycyclic hydrocarbons in samples collected during the six-month period July 31, 1961 to January 31, 1962 are shown in Table 3. These have been arranged in two quarterly periods, and the first of these includes an analysis of filters from the preliminary experiments in August on which the amount of smoke had been estimated indirectly. The concentrations of these pollutants were found to be higher in the air of Fleet Street than at the control site, and 
more pollution was found in the air at both sites in period 2 (November to January) than during period 1 (August to October). The amount of pollution attributable to traffic in Fleet Street has been estimated by subtracting the concentrations at site $B$ from those at site A. Before drawing any further conclusions from these results, we considered that it would be advisable to repeat the experiments for a complete 12-month period and to include samples from an additional control site (our laboratory, site $\mathrm{C})$. We also decided to determine lead in the samples since this pollutant had been found to be a useful index of pollution by petrol vehicles (Waller et al., 1961).

There was an interval of one month before our new sampling programme was started on March 6, 1962. The filters were again grouped in quarterly periods for analysis, and the results from the first two quarters, which can be regarded as summer, are given in Table 4 . There was more pollution by

TABLE 3

CONCENTRATION OF SMOKE AND HYDROCARBONS IN FLEET STREET AND AT CONTROL SITE, 1961-62

\begin{tabular}{|c|c|c|c|c|c|c|c|c|c|}
\hline \multirow{2}{*}{$\begin{array}{l}\text { Period } \\
\text { Site }\end{array}$} & \multicolumn{3}{|c|}{ July $\stackrel{1}{31-O c t o b e r} 31,1961$} & \multicolumn{3}{|c|}{$\begin{array}{l}2 \\
\text { October } 31,1961- \\
\text { January } 31,1962\end{array}$} & \multicolumn{3}{|c|}{$\begin{array}{l}1-2 \\
\text { Mean }\end{array}$} \\
\hline & $\mathbf{A}$ & B & Diff. & $\mathbf{A}$ & B & Diff. & $\mathbf{A}$ & B & Diff. \\
\hline Smoke ( $\left.\mu \mathrm{g} . / \mathrm{m} .^{3}\right)$ & 370 & 82 & 288 & 536 & 336 & 200 & 453 & 209 & 244 \\
\hline $\begin{array}{l}\text { Hydrocarbons }\left(\mu \mathrm{g} . / 1000 \mathrm{~m} \cdot{ }^{3} \text { air }\right) \\
\text { 3:4-benzpyrene } \\
1: 2 \text {-benzpyrene } \\
1: 12 \text {-benzperylene } \\
\text { Coronene } \\
\text { Anthanthrene }\end{array}$ & $\begin{array}{r}14 \\
11 \\
35 \\
16 \\
4\end{array}$ & $\begin{array}{l}4 \\
2 \\
4 \\
2 \\
*\end{array}$ & $\begin{array}{r}10 \\
9 \\
31 \\
14 \\
4\end{array}$ & $\begin{array}{l}58 \\
34 \\
72 \\
26 \\
12\end{array}$ & $\begin{array}{r}34 \\
24 \\
34 \\
7 \\
5\end{array}$ & $\begin{array}{r}24 \\
10 \\
38 \\
19 \\
7\end{array}$ & $\begin{array}{r}36 \\
22 \\
54 \\
21 \\
8\end{array}$ & $\begin{array}{r}19 \\
13 \\
19 \\
4 \\
3\end{array}$ & $\begin{array}{r}17 \\
9 \\
35 \\
17 \\
5\end{array}$ \\
\hline $\begin{array}{l}\text { Hydrocarbons }(\mu \mathrm{g} . / \mathrm{g} . \text { smoke) } \\
\text { 3:4-benzpyrene } \\
1: 2 \text {-benzpyrene } \\
1: 12 \text {-benzperylene } \\
\text { Coronene } \\
\text { Anthanthrene }\end{array}$ & $\begin{array}{l}38 \\
31 \\
95 \\
43 \\
12\end{array}$ & $\begin{array}{l}49 \\
29 \\
44 \\
23 \\
*\end{array}$ & $\begin{array}{r}35 \\
31 \\
108 \\
49 \\
14\end{array}$ & $\begin{array}{r}108 \\
63 \\
135 \\
49 \\
23\end{array}$ & $\begin{array}{r}101 \\
71 \\
101 \\
21 \\
15\end{array}$ & $\begin{array}{r}120 \\
50 \\
190 \\
95 \\
35\end{array}$ & $\begin{array}{r}73 \\
47 \\
115 \\
46 \\
18\end{array}$ & $\begin{array}{l}75 \\
50 \\
72 \\
22 \\
10\end{array}$ & $\begin{array}{r}78 \\
40 \\
149 \\
72 \\
24\end{array}$ \\
\hline
\end{tabular}

*Barely measurable, concentration less than $0.5 \mu \mathrm{g} . / 1000 \mathrm{~m}^{3}$ air (less than $5 \mu \mathrm{g} . / \mathrm{g}$. smoke): upper limits used when calculating means.

TABLE 4

CONCENTRATION OF SMOKE AND HYDROCARBONS IN FLEET STREET AND AT CONTROL SITES, SUMMER 1962

\begin{tabular}{|c|c|c|c|c|c|c|c|c|c|c|c|c|}
\hline \multirow{2}{*}{$\begin{array}{l}\text { Period } \\
\text { Site }\end{array}$} & \multicolumn{4}{|c|}{ March 6-June 7, 1962} & \multicolumn{4}{|c|}{$\stackrel{4}{4}$ June 7 -August 31,1962} & \multicolumn{4}{|c|}{ Summer Mean } \\
\hline & $\mathbf{A}$ & B & C & Diff. & A & B & C & Diff. & $\mathbf{A}$ & $\mathbf{B}$ & C & Diff. \\
\hline $\begin{array}{l}\text { Smoke }\left(\mu \mathrm{g} . / \mathrm{m}^{3}\right) \\
\text { Lead }\left(\mu \mathrm{g} . / \mathrm{m}^{3}\right)\end{array}$ & $\begin{array}{r}537 \\
4 \cdot 8\end{array}$ & 112 & $\begin{array}{r}121 \\
\dagger\end{array}$ & 421 & $\begin{array}{r}303 \\
1.6\end{array}$ & $\begin{array}{r}90 \\
+\end{array}$ & $\begin{array}{r}67 \\
+\end{array}$ & $\frac{225}{1 \cdot 1}$ & $\begin{array}{r}420 \\
3 \cdot 2\end{array}$ & $\begin{array}{r}101 \\
+\end{array}$ & 94 & $\stackrel{322}{2 \cdot 7}$ \\
\hline $\begin{array}{l}\text { Hydrocarbons }\left(\mu \mathrm{g} . / 1000 \mathrm{~m} \cdot{ }^{3} \text { air }\right) \\
\text { 3:4-benzpyrene } \\
1: 2 \text {-benzpyrene } \\
1: 12 \text {-benzperylene } \\
\text { Coronene } \\
\text { Anthanthrene }\end{array}$ & $\begin{array}{r}20 \\
14 \\
36 \\
18 \\
2\end{array}$ & $\begin{array}{r}12 \\
3 \\
8 \\
2 \\
*\end{array}$ & $\begin{array}{r}10 \\
6 \\
6 \\
1 \\
*\end{array}$ & $\begin{array}{r}9 \\
10 \\
29 \\
16 \\
2\end{array}$ & $\begin{array}{r}11 \\
11 \\
28 \\
12 \\
3\end{array}$ & $\begin{array}{l}1 \\
1 \\
* \\
*\end{array}$ & $\begin{array}{l}1 \\
1 \\
* \\
* \\
*\end{array}$ & $\begin{array}{r}10 \\
10 \\
28 \\
12 \\
3\end{array}$ & $\begin{array}{r}16 \\
12 \\
32 \\
15 \\
2\end{array}$ & $\begin{array}{l}6 \\
2 \\
4 \\
1 \\
*\end{array}$ & $\begin{array}{l}6 \\
4 \\
3 \\
1 \\
*\end{array}$ & $\begin{array}{r}10 \\
10 \\
28 \\
14 \\
2\end{array}$ \\
\hline $\begin{array}{l}\text { Hydrocarbons }(\mu \mathrm{g} . / \mathrm{g} . \text { smoke) } \\
\text { 3:4-benzpyrene } \\
\text { 1:2-benzpyrene } \\
1: 12 \text {-benzperylene } \\
\text { Coronene } \\
\text { Anthanthrene }\end{array}$ & $\begin{array}{l}38 \\
26 \\
67 \\
34 \\
*\end{array}$ & $\begin{array}{r}110 \\
30 \\
70 \\
20 \\
*\end{array}$ & $\begin{array}{l}81 \\
52 \\
52 \\
11 \\
*\end{array}$ & $\begin{array}{l}21 \\
24 \\
69 \\
38 \\
*\end{array}$ & $\begin{array}{l}37 \\
37 \\
93 \\
40 \\
11\end{array}$ & $\begin{array}{r}10 \\
10 \\
* \\
*\end{array}$ & $\begin{array}{l}8 \\
8 \\
* \\
*\end{array}$ & $\begin{array}{r}44 \\
44 \\
124 \\
53 \\
13\end{array}$ & $\begin{array}{r}38 \\
32 \\
80 \\
37 \\
8\end{array}$ & $\begin{array}{l}60 \\
20 \\
38 \\
10 \\
*\end{array}$ & $\begin{array}{r}44 \\
30 \\
28 \\
8 \\
*\end{array}$ & $\begin{array}{r}32 \\
34 \\
96 \\
46 \\
9\end{array}$ \\
\hline
\end{tabular}

*Barely measurable, concentration less than $0.5 \mu \mathrm{g} . / 1000 \mathrm{~m} .^{3}$ air (less than $5 \mu \mathrm{g} . / \mathrm{g}$. smoke): upper limits used when calculating means.

Less than $0.5 \mathrm{\mu g} . / \mathrm{m}^{3}$.

The results in Tables 3 to 6 all refer to the hours of 08.00 to 19.00 , Mondays to Fridays only. The difference columns give the estimated traffic pollution: the concentrations in $\mu \mathrm{g} . / \mathrm{m} .^{3}$ air have been obtained by subtracting the background pollution (at site $B$ in Table 3 , and the mean of sites $B$ and $C$ in Tables 45 , and 6) from that in Fleet Street (site A), and the amounts of hydrocarbons in $\mu \mathrm{g} . / \mathrm{g}$. have then been calculated from the concentrations. Mean amounts of hydrocarbons in $\mu \mathrm{g} . / \mathrm{g}$. have been calculated from the values in the separate periods, and not from the mean concentrations of smoke and hydrocarbons. 
TABLE 5

CONCENTRATION OF SMOKE AND HYDROCARBONS IN FLEET STREET AND AT CONTROL SITES, WINTER 1962-63

\begin{tabular}{|c|c|c|c|c|c|c|c|c|c|c|c|c|}
\hline \multirow{2}{*}{ Period } & \multicolumn{4}{|c|}{ September $\underset{1962}{5}$-December 7, } & \multicolumn{4}{|c|}{$\begin{array}{c}6 \\
\text { December 10, } 1962- \\
\text { March 1, } 1963\end{array}$} & \multicolumn{4}{|c|}{ Winter, $1962-63$} \\
\hline & $\mathbf{A}$ & B & $\mathrm{C}$ & Diff. & $\mathbf{A}$ & B & C & Diff. & $\mathbf{A}$ & B & C & Diff. \\
\hline $\begin{array}{l}\text { Smoke }\left(\mu \mathrm{g} . / \mathrm{m}^{3}\right) \\
\text { Lead }\left(\mu \mathrm{g} . / \mathrm{m}^{3}\right)\end{array}$ & $\begin{array}{r}439 \\
4 \cdot 4\end{array}$ & 160 & $\begin{array}{r}221 \\
1 \cdot 6\end{array}$ & $\begin{array}{r}249 \\
2 \cdot 6\end{array}$ & $\begin{array}{r}440 \\
2 \cdot 1\end{array}$ & 182 & 189 & 254 & $\begin{array}{r}440 \\
3 \cdot 2\end{array}$ & $171 \cdot 2$ & $\underset{1.0}{205}$ & $\begin{array}{r}252 \\
2 \cdot 1\end{array}$ \\
\hline $\begin{array}{l}\text { Hydrocarbons }\left(\mu \mathrm{g} . / 1000 \mathrm{~m}^{3} \text { air }\right) \\
\text { 3:4-benzpyrene } \\
1: 2 \text {-benzpyrene } \\
1: 12 \text {-benzperylene } \\
\text { Coronene } \\
\text { Anthanthrene }\end{array}$ & $\begin{array}{l}57 \\
38 \\
59 \\
24 \\
10\end{array}$ & $\begin{array}{r}30 \\
20 \\
17 \\
6 \\
3\end{array}$ & $\begin{array}{r}46 \\
27 \\
31 \\
8 \\
5\end{array}$ & $\begin{array}{r}19 \\
14 \\
35 \\
17 \\
6\end{array}$ & $\begin{array}{l}68 \\
39 \\
63 \\
26 \\
11\end{array}$ & $\begin{array}{r}38 \\
28 \\
22 \\
6 \\
2\end{array}$ & $\begin{array}{r}46 \\
30 \\
31 \\
7 \\
4\end{array}$ & $\begin{array}{r}26 \\
10 \\
37 \\
20 \\
8\end{array}$ & $\begin{array}{l}62 \\
38 \\
61 \\
25 \\
10\end{array}$ & $\begin{array}{r}34 \\
24 \\
20 \\
6 \\
2\end{array}$ & $\begin{array}{r}46 \\
28 \\
31 \\
8 \\
4\end{array}$ & $\begin{array}{r}22 \\
12 \\
35 \\
18 \\
7\end{array}$ \\
\hline $\begin{array}{l}\text { Hydrocarbons }(\mu \mathrm{g} . / \mathrm{g} . \text { smoke) } \\
\text { 3:4-benzpyrene } \\
1: 2 \text {-benzpyrene } \\
1: 12 \text {-benzperylene } \\
\text { Coronene } \\
\text { Anthanthrene }\end{array}$ & $\begin{array}{r}130 \\
87 \\
134 \\
55 \\
23\end{array}$ & $\begin{array}{r}190 \\
123 \\
109 \\
40 \\
18\end{array}$ & $\begin{array}{r}207 \\
124 \\
140 \\
35 \\
22\end{array}$ & $\begin{array}{r}76 \\
56 \\
141 \\
68 \\
24\end{array}$ & $\begin{array}{r}154 \\
88 \\
143 \\
60 \\
26\end{array}$ & $\begin{array}{r}212 \\
153 \\
121 \\
31 \\
13\end{array}$ & $\begin{array}{r}244 \\
161 \\
155 \\
39 \\
19\end{array}$ & $\begin{array}{r}102 \\
39 \\
146 \\
79 \\
31\end{array}$ & $\begin{array}{r}142 \\
88 \\
138 \\
58 \\
24\end{array}$ & $\begin{array}{r}201 \\
138 \\
115 \\
36 \\
16\end{array}$ & $\begin{array}{r}226 \\
142 \\
152 \\
37 \\
20\end{array}$ & $\begin{array}{r}89 \\
48 \\
144 \\
74 \\
28\end{array}$ \\
\hline
\end{tabular}

*Barely measurable, concentration less than $0.5 \mu \mathrm{g} . / \mathrm{m}^{3}$ : upper limit used when calculating means.

TABLE 6

SUMMARY OF RESULTS, WHOLE YEAR 1962-63

\begin{tabular}{|c|c|c|c|c|c|c|c|}
\hline Site & $\mathbf{A}$ & B & C & $\begin{array}{c}\text { Mean } \\
\text { Background }\end{array}$ & $\begin{array}{c}\text { Traffic } \\
\text { Pollution }\end{array}$ & $\begin{array}{l}\text { Ratio } \\
\text { A/Back- } \\
\text { ground }\end{array}$ & $\begin{array}{l}\text { Traffic } \\
\text { Pollution } \\
\text { as } \% \mathrm{~A}\end{array}$ \\
\hline $\begin{array}{l}\text { Smoke }\left(\mu \mathrm{g} . / \mathrm{m}^{3}\right) \\
\text { Lead }\left(\mu \mathrm{g} . / \mathrm{m}^{3}\right) \\
\text { Lead }(\% \text { smoke })\end{array}$ & $\begin{array}{r}430 \\
3 \cdot 2 \\
0 \cdot 7\end{array}$ & $\begin{array}{r}136 \\
0.8 \\
0.6\end{array}$ & $\begin{array}{r}150 \\
0.8 \\
0.5\end{array}$ & $\begin{array}{r}143 \\
0.8 \\
0.6\end{array}$ & $\begin{array}{r}287 \\
2.4 \\
0.8\end{array}$ & $\begin{array}{r}3 \cdot 0 \\
4 \cdot 0 \\
-\end{array}$ & $\begin{array}{l}67 \\
75 \\
-\end{array}$ \\
\hline $\begin{array}{l}\text { Hydrocarbons }\left(\mu \mathrm{g} . / 1000 \mathrm{~m}^{3} \text { air }\right) \\
\text { 3:4-benzpyrene } \\
1: 2 \text {-benzpyrene } \\
1: 12 \text {-benzperylene } \\
\text { Coronene } \\
\text { Anthanthrene }\end{array}$ & $\begin{array}{r}39 \\
26 \\
46 \\
20 \\
6\end{array}$ & $\begin{array}{r}20 \\
13 \\
12 \\
4 \\
2\end{array}$ & $\begin{array}{r}26 \\
16 \\
17 \\
4 \\
2\end{array}$ & $\begin{array}{r}23 \\
14 \\
14 \\
4 \\
2\end{array}$ & $\begin{array}{r}16 \\
12 \\
32 \\
16 \\
4\end{array}$ & $\begin{array}{l}1 \cdot 7 \\
1 \cdot 9 \\
3 \cdot 3 \\
5 \cdot 0 \\
3 \cdot 0\end{array}$ & $\begin{array}{l}41 \\
46 \\
70 \\
80 \\
67\end{array}$ \\
\hline $\begin{array}{l}\text { Hydrocarbons ( } \mu \mathrm{g} . / \mathrm{g} . \text { smoke) } \\
\text { 3:4-benzpyrene } \\
1: 2 \text {-benzpyrene } \\
1: 12 \text {-benzperylene } \\
\text { Coronene } \\
\text { Anthanthrene }\end{array}$ & $\begin{array}{r}90 \\
60 \\
109 \\
47 \\
16\end{array}$ & $\begin{array}{r}130 \\
79 \\
76 \\
24 \\
10\end{array}$ & $\begin{array}{r}135 \\
86 \\
90 \\
22 \\
13\end{array}$ & $\begin{array}{r}132 \\
82 \\
83 \\
23 \\
12\end{array}$ & $\begin{array}{r}61 \\
41 \\
120 \\
60 \\
18\end{array}$ & $\begin{array}{l}\text { E } \\
\text { - }\end{array}$ & $\bar{E}$ \\
\hline
\end{tabular}

smoke, lead, and hydrocarbons in the air of Fleet Street than at either of the control sites, and the mean concentrations for these two quarters were similar to those for the summer quarter of the first part of our study (period 1, Table 3). There was little difference between the concentrations at the two control sites and we considered that the best estimate of the general background pollution of the area would be given by the mean of these results. In this table, therefore, the traffic pollution has been calculated by subtracting the mean concentrations at sites $B$ and $C$ from those at site $A$. In the determinations of lead, the amounts found in the samples from the two control sites were only a little higher than the blank determinations made on clean filters, and it was therefore only possible to give approximate results.

Results from the next two quarters are shown in
Table 5. Both of these have been taken as being representative of winter conditions, for although period 5 started in September when the weather was warm and the background pollution was low, it included the severe fog episode in London during the first few days of December, when pollution was exceptionally high, and the mean concentrations of pollution over the three months were similar to those in period 6. The mean concentrations for these two periods were also similar to those found in the winter quarter of the first part of the study (period 2, Table 3). There were some differences between the concentrations of each of the pollutants at the two control sites, and the means have been used in calculating the traffic pollution.

Results for the whole year have been brought together in Table 6. The traffic pollution contains the same polycyclic hydrocarbons as were found in 
the general background smoke (predominantly from coal fires), but the proportions of the individual hydrocarbons in the smoke were different. In the background pollution 3:4-benzpyrene was predominant among the five hydrocarbons determined whilst in the traffic pollution 1:12-benzperylene predominated. In Table 6 the traffic pollution has also been expressed as a percentage of the total pollution in Fleet Street. In general terms this shows that in the street more than half of the smoke, lead, 1:12-benzperylene, coronene, and anthanthrene and less than half of the 1:2-benzpyrene and 3:4-benzpyrene comes from the traffic. Of all the seven pollutants determined here, the carcinogen 3:4-benzpyrene was the one least associated with traffic. For the year as a whole, the differences between the concentrations of each pollutant at the two control sites were not great and though the traffic pollution has been calculated using the means of the concentrations at sites $B$ and $C$, the results would not be materially affected by using only those from Mitre Court (site B). Comparing Tables 3 and 6, the traffic pollution is seen to be very similar in the two periods, and we might therefore consider that the results from the six-month preliminary experiment, which included one summer and one winter quarter, are equivalent to those for a whole year.

\section{Discussion}

It must be emphasized that our sampling inlet at the Fleet Street site was very close to the exhaust pipes of passing vehicles. We had intentionally chosen a site at the centre of the road so that we would be able to assess the maximum concentration of traffic pollution to which a pedestrian may be exposed in streets. The pollution here is likely to be greater than that at the pavement since many vehicles, notably those with diesel engines, discharged their exhaust products from the offside towards our sampling inlet. Despite the large amount of traffic pollution at this special site at the centre of the road, it is clear that the concentration falls off rapidly, for at Mitre Court, only 150 feet $(46 \mathrm{~m}$.) away, there is no evidence of an appreciable amount of pollution from the traffic in Fleet Street. From Tables 4 and 5 we can see that, in general, the pollution at Mitre Court (B) was similar to that at St. Bartholomew's Hospital (C), which is more remote from heavy traffic. Reed and Barrett (1965) have also shown that the concentrations of traffic pollution fall off rapidly with distance from busy roads.

Although there are likely to be large variations in the emission and dispersion of traffic pollution between one site and another, it is of interest to compare our results with those reported from other cities. At a congested point on a major highway in Sydney, Sullivan and Cleary (1964) found an average concentration of 3:4-benzpyrene of $24 \cdot 2 \mu \mathrm{g}$. $/ 1000 \mathrm{~m}^{3}$ in mixed petrol and diesel traffic during evening rushhours only, with a background concentration of $2 \cdot 2 \mu \mathrm{g} . / 1000 \mathrm{~m}^{3}$. Our mean annual figure for weekday daytime in Fleet Street was $39 \mu \mathrm{g} . / 1000 \mathrm{~m}^{3}$, with a background concentration of $23 \mu \mathrm{g} . / 1000 \mathrm{~m}^{3}$. Although the traffic component as reported is higher in the Sydney study, variations of this magnitude could easily arise through differences in sampling periods or traffic conditions.

The amounts of lead which we found in Fleet Street are similar to those reported from other cities. Cholak (1964) quotes concentrations ranging from 2.0 to $7.7 \mu \mathrm{g} . / \mathrm{m}^{3}$ in the streets of Cincinnati, and Moureu (1964) has reported 5.07 to $9.80 \mu \mathrm{g} . / \mathrm{m}^{3}$ at busy traffic junctions in Paris. In each of these studies the measurements were confined to weekday daytime periods, and the results might be compared with our figure of $3.2 \mu \mathrm{g} . / \mathrm{m}^{3}$ for the mean annual concentration during these periods in Fleet Street. Many factors could be considered to explain the somewhat higher figures reported from Paris. Moureu gave the traffic flow at his sampling points as 1,000 to 2,000 vehicles per hour, but he did not distinguish between petrol and diesel vehicles. Only the petrol traffic would contribute to the lead content of the air, since lead compounds are added as an anti-knock to petrol and not to diesel oil. Even if all the vehicles passing the Paris sampling points were counted as having petrol engines, the flow would seem to be not much greater than the 1,200 petrol vehicles per hour which we counted in Fleet Street. Moureu also gave detailed figures for the concentration of carbon monoxide at his Paris sampling points: the mean concentration during the daytime hours was very close to the 17 p.p.m. found in our own study. Both lead and carbon monoxide are emitted from petrol rather than diesel traffic, and in our tunnel experiments we had found an appropriate close correlation between the concentrations of these pollutants. Since the carbon monoxide concentrations were similar in Paris and Fleet Street, the differences in the amounts of lead may have been due to differences in background concentration or to differing lead contents of the fuel in the two countries.

Our interest in lead was mainly as an indicator of pollution from petrol vehicles, and we do not consider that the $3.2 \mu \mathrm{g} . / \mathrm{m}^{3}$ which we found at our Fleet Street site constitutes any appreciable hazard to health. The subject was discussed by the Surgeon General in his Report to the U.S. Congress (U.S. Public Health Service, 1962). He considers that 'The maximal atmospheric lead levels currently 
observed have been much too low to produce clinical evidence of lead poisoning . . . But ... there are many questions still to be answered'. The questions posed in this report relate to possible effects of longterm exposure to small doses, the effect of lead on babies and sick people, and hitherto unknown effects of the metal. Against this must be set the reassuring experience gained from latter day industrial exposure where the maximum allowable concentration is $200 \mu \mathrm{g} . / \mathrm{m}^{3}$ The estimate suggested as a possible standard in the Technical Report of California Standards for Ambient Air Quality (State of California, 1960) is $6 \mu \mathrm{g} . / \mathrm{m}^{3}$, and it is reassuring that our Fleet Street results are less than this. Our highest quarterly result was $4.8 \mu \mathrm{g} . / \mathrm{m}^{3}$ but no one is exposed to this continuously.

The seasonal differences in pollution, which are evident in Tables 4 and 5 (and within Table 3), call for some comment. We expected to find seasonal variations in the concentrations of all the pollutants at the control sites since the emission from most sources is greater in the colder months. We did not know whether the emission of pollution by the traffic in Fleet Street would vary from one season to another, nor could we forecast variations in the dispersion conditions at our sampling point. The expected seasonal variation in background pollution (sites B and C) is evident in Tables 4 and 5 and it can also be seen within Table 3 . There is an exceptionally high figure for the smoke concentration in the first winter period at site B (period 2, Table 3); if the results for this period are compared with those from the other winter periods (5 and 6) at the same site, it can be seen that the hydrocarbon concentrations are not exceptionally high in period 2 . This suggests that the additional 'smoke' at this time was hydrocarbon-free dust. We have no evidence of the source of this dust, but it was known that building demolition and reconstruction was in progress in the vicinity. The smoke concentration was also high at site $\mathbf{A}$, not only in this period but also in period 3 . It seems likely that hydrocarbon-free dust was responsible for the excess: it may have come either from building sites or from the road surfaces and we cannot, with the limited information available, explain why there was excess dust at sites $A$ and $B$ in period 2 but only at site $A$ in period 3 . It would be difficult to determine how far variations in turbulence, wind speed and direction, and rain or snow on the road would affect the amount of material collected on our filters. We cannot therefore learn much from small differences between the results for individual periods, and even the mean seasonal figures given in the final columns of Tables 4 and 5 are of limited significance. The amount of smoke attributable to traffic appears to be higher in summer than in winter, but the range in the three summer periods $(1,3$, and 4$)$ is wide, and we cannot draw any firm conclusions from the comparison of these seasonal means. However, the concentrations of hydrocarbons in the air are not affected by the type of dust which appears to be interfering with the smoke determinations, and the concentrations are consistently higher at all sites in the winter periods $(2,5$, and 6$)$ than in the summer periods $(1,3$, and 4$)$. This seasonal difference is apparent even in the estimated traffic component: in the case of coronene, 1:12-benzperylene, and 1:2-benzpyrene, the differences are small, but for 3:4-benzpyrene and anthanthrene they are large enough to call for some comment. We have considered possible reasons for a seasonal variation in traffic pollution in Fleet Street; examination of traffic census records for the whole of London did not reveal any consistent seasonal variation in the amount of traffic, but we gained the general impression that there is less traffic in central London streets in the summer months, when people are on holiday, than in the winter. Through the courtesy of London Transport we were able to examine records of delays to buses in Fleet Street during the period of our experiments there. These gave a valuable guide to the degree of congestion during the busy periods of each day, and they showed minimum congestion during the summer months. The maximum delays occurred just before Christmas when there was additional traffic for shopping. Increased congestion causes frequent interruptions in the flow of traffic and the greater amount of fuel required would lead to an increased emission of at least some of the pollutants. Severe congestion could, of course, lead to a complete stoppage of the traffic with reduction in pollution once engines were switched off.

The following possible explanations of seasonal variations in estimated traffic pollution were considered:

(a) We cannot be sure that in one year we have made an adequate assessment of the background pollution in Fleet Street. Although we chose our sites carefully to avoid interference by any local sources of smoke, it is possible that in winter smoke from chimneys could have affected our control sites (B and C) more than our ground level site (A) in Fleet Street.

(b) Apart from variations in the total amount of traffic in Fleet Street there may also be variations in its composition. There were no major differences in the number of buses using Fleet Street in summer and winter, but we could not determine whether there were any differences in the number of taxis, which form an important fraction of the traffic there. The gradual introduction of one-way streets in the central 
London area during the course of our study may have had some effect on the type and amount of traffic using Fleet Street.

(c) We have considered the variations in wind speed and direction as measured at the nearby Meteorological Office but these could not account for consistent seasonal changes in traffic pollution. We also considered the frequency of winds blowing straight along Fleet Street, which would be more effective than winds from other directions in dispersing the traffic pollution at our sampling point, but there was no suggestion that concentrations might be expected to be higher in winter: but the data on wind, which were recorded at roof level, might not have been a sufficiently good guide to the turbulence in Fleet Street.

(d) There were differences in the temperatures of the filter holders at the three sampling sites; in summer these differences were small, but in winter they were large, because the filters at sites B and C were in centrally heated buildings whereas that at $\mathrm{A}$ was only partially protected from the outside air. Some experiments were carried out in the laboratory to find out whether any loss of hydrocarbons occurred from a warm sample compared with a cold one. Had such a loss been observed, the results from the control sites would have been too low to enable a direct comparison to be made with those in Fleet Street and the traffic component would have appeared greater in winter. But no significant differences were noted in respect of the hydrocarbons determined in this study. In the case of the more volatile hydrocarbons, such as pyrene, fluoranthene, phenanthrene, and anthracene, the effect is large, and this was the reason for confining our reported analyses in the tables to the five hydrocarbons quoted.

(e) In our results the seasonal differences were marked only in the case of 3:4-benzpyrene and anthanthrene. Some hydrocarbons can be decomposed by sunlight or by reaction with gases in the air, and therefore we did additional experiments to study these effects. The effects of two gases known to be present in Fleet Street, $\mathrm{SO}_{2}$ and $\mathrm{NO}_{2}$, were studied, but the results did not provide a complete answer to our problem. Anthanthrene and 3:4-benzpyrene are preferentially decomposed by sunlight, and this effect would reduce the amounts of these hydrocarbons found in the summer months, but very little sunshine penetrates there even in midsummer and this finding was therefore of little relevance. Details of this supplementary work will be published elsewhere.

We had hoped that we would obtain some further clue about variations in traffic pollution from our determinations of lead. There was no difference between the mean summer and winter concentrations of lead in Fleet Street (site A, Tables 4 and 5), but there were erratic variations from one quarterly period to another. It is possible that some leadcontaining dust (e.g., road dust) was picked up by the Fleet Street sampler and not by those at the control sites. The highest concentration observed (period 3 ) is associated with a high concentration of smoke, where we suspect that some dust may have been sampled.

Traffic pollution can be characterized by the relative abundance of certain hydrocarbons. Extensive studies (Commins, to be published) have shown that coal smoke contains more 1:2- and 3:4-benzpyrene than traffic smoke. In period 6 , when the background pollution was predominantly coal smoke, the amounts of 1:2- and 3:4-benzpyrene in the smoke at sites $B$ and C (Table 5) were approximately four times those derived from the most reliable estimate of the traffic pollution (whole year, Table 6). In contrast, there is less coronene in coal smoke than in that from traffic.

An alternative approach to this problem is to consider the pollution in Fleet Street during a midsummer period (4) to be derived wholly from traffic, since the background was very low. These results show a similar pattern, with relatively low amounts of 1:2- and 3:4-benzpyrene. A useful index of the amount of traffic smoke in a given sample can be obtained by calculating the ratio of coronene to 1:2-benzpyrene. This ratio is 0.24 for the "coal smoke' of period 6 (Table 5 , site C), and 1.5 for our estimate of traffic pollution (Table 6). Ratios as high as this have been found in other studies (Commins, to be published) in which traffic was the main source of pollution. In all the winter periods $(2,5$, and 6$)$ the ratios of the hydrocarbons at the control sites (B and C) are characteristic of coal smoke, and in some of the summer periods the ratios are similar. In Table 6 the mean background over the whole year appears to be coal smoke (coronene/1:2-benzpyrene $=0 \cdot 28$ ) and the amounts of $1: 2$ - and 3:4-benzpyrene in traffic pollution were half those present in the mean background. There was about one and a half times as much 1:12-benzperylene and anthanthrene and two and a half times as much coronene in the traffic smoke as there was in the background.

In the limited study that we have reported in this paper we cannot establish with certainty whether the seasonal variations in traffic pollution were real. Our doubts about them at least serve as a warning that samples taken over a limited period may not give a complete picture of traffic pollution in coalburning areas, and in forming our general conclusions we have turned to Table 6 , which summarizes the results over the complete 12-month period. 
The only people whose exposure to smoke, lead, and polycyclic hydrocarbons might be appreciably increased by the emissions from road vehicles are those such as traffic policemen who spend long periods in the midst of congested traffic. At our Fleet Street site the point-duty policeman stood very close to our sampling inlet, near the centre of the road, and spent up to two and a half hours there at a time. During such periods he would, according to the results quoted in Table 6 , have been exposed on average to three times as much smoke, four times as much lead, and 1.7 times as much 3:4-benzpyrene as other City workers who were not so close to congested traffic. Even so, his overall exposure to these pollutants would not be greatly affected by these short periods of duty, and the only hazard might be from high concentrations of carbon monoxide. Recently traffic lights have been installed at the junction where our samples were taken, and there is no longer a policeman on duty there.

We were particularly interested in the possibility of increased exposure to 3:4-benzpyrene, but it can be seen that even in the worst situation, at our sampler, the concentration of this substance is only 1.7 times the background level, and the excess persists only during the busy periods, i.e., for about 11 of the 24 hours on weekdays. News vendors and others who work in the streets, and drivers who spend long periods in congested traffic, might also be affected, but the results do not suggest that the long-term exposure of these people to 3:4-benzpyrene differs much from that of other London dwellers.

In Fig. 4 we have compared the results from Fleet
Street with those obtained in some of our earlier studies. In some cases the concentrations expected during weekday daytime periods have been estimated from results covering whole days, and the diagram indicates approximate values only. The Mersey Tunnel results were based on those quoted by Stocks, Commins, and Aubrey (1961), but the smoke concentration was re-calculated on a gravimetric basis. There was less traffic smoke in Fleet Street than in the Blackwall or Mersey Tunnels, and the amount found there was no greater than the general background smoke in some large towns in Great Britain (e.g., Salford). If the traffic conditions found in Fleet Street existed in a rural area such as the Conway Valley (a remote area in North Wales included in an earlier study: Commins, 1958b), the concentration of smoke close to the traffic would be many times that in the general background there. The amount of 3:4-benzpyrene contributed by traffic at our sampling point in the middle of Fleet Street was less than the general background concentration in large towns, and was about the same as that found in one of the small towns (Wetherby) included in an earlier study (Stocks et al., 1961).

We can conclude from these results that at the present time the contribution made by traffic to the 3:4-benzpyrene content of the air of streets is small in comparison with the relatively large amounts that are put into the general atmosphere from the inefficient combustion of coal. The implementation of the Clean Air Act (1956), by which the emission of smoke with its associated 3:4-benzpyrene is restricted, will lead eventually to reduced background levels of 3:4-benzpyrene everywhere. The
Fig. 4.-Mean annual concentrations of smoke and 3:4-benzpyrene in Fleet Street compared with those at other sites (weekday daytime only). The blocks represent the total pollution at each site and the unshaded portions indicate the traffic component.

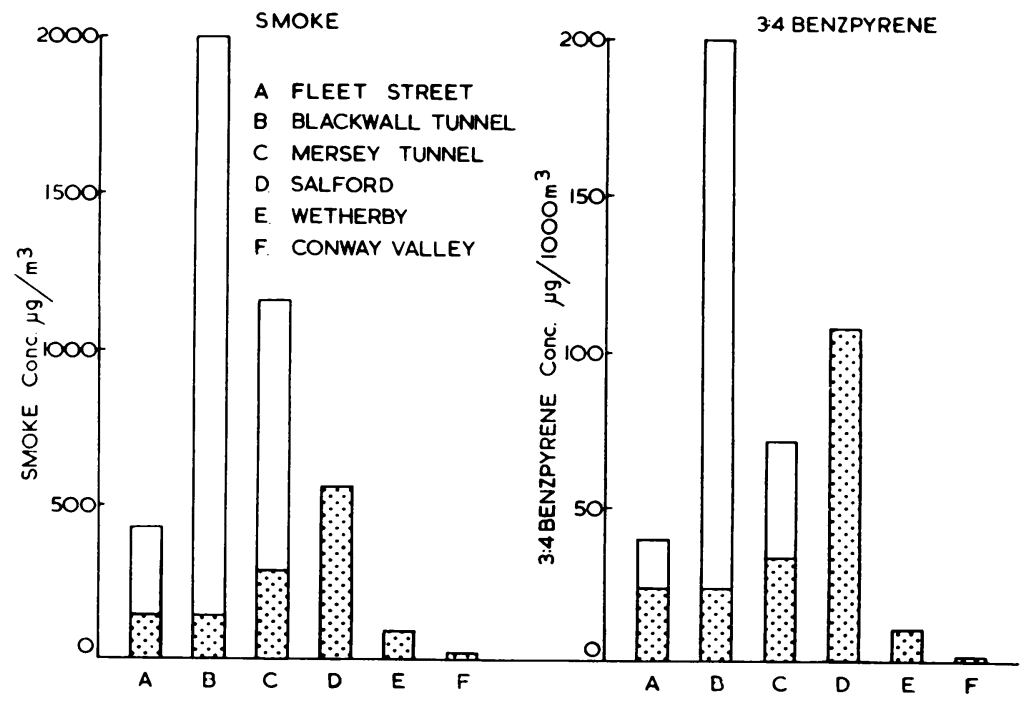


emissions from traffic might then be left as the major source of smoke and 3:4-benzpyrene in town air, but the concentrations of these pollutants would only be appreciable in the immediate vicinity of the traffic.

Valuable assistance was given by Mr. L. Hampton and other members of the Air Pollution Research Unit. We are indebted to the Corporation of the City of London and to Dr. Hugh Richards for providing accommodation for some of the sampling equipment used in this experiment.

\section{REFERENCES}

British Standards Institution (1964). B.S. 1747. Part 2. Cholak, J. (1964). Arch, environm. Hlth, 8, 314.
Clean Air Act (1956). H.M. Stationery Office, London.

Commins, B. T. (1958a). Analyst, 83, 386.

(1958b). Int. J. Air Pollut., 1, 14.

- (1961). National Cancer Institute. Monograph No. 9. 225.

Committee on Air Pollution (1954). Report. H.M. Stationery Office, London.

Harrold, G. C., Meek, S. J., and Holden, F. R. (1936). J. industr.

Hyg., 18, 724.
Lawther, P. J., Commins, B. T., and Henderson, M. (1962). Ann.

occup. Hyg., 5, 241.
Moureu, H. (1964). Proc. roy. Soc. Med., 57, 1015.

Reed, L. E. (1963). Int. J. Air Wat. Pollut., 7, 979.

- and Barrett, C. F. (1965). Ibid., in the Press.

State of California (1960). Technical Report of California Standards for Ambient Air Quality and Motor Vehicle Exhaust. Department of Public Health, Berkeley.

Stocks, P., Commins, B. T., and Aubrey, K. V. (1961). Int. J. Air Wat. Pollut., 4, 141.

Sullivan, J. L., and Cleary, G. J. (1964). Brit. J. industr. Med., 21, 117.

U.S. Public Health Service (1962). Motor Vehicles, Air Pollution and Health, U.S. Government Printing Office, Washington.

Waller, R. E., Commins, B. T., and Lawther, P. J. (1961). Brit. J. industr. Med., 18, 250. 